Buletin JSJ, 1 (2), 2019, 81-77

Available online di: http://ejournal-balitbang.kkp.go.id/index.php/JSJ/index

\title{
ASPEK BIOLOGI IKAN BELANAK (Mugil cephalus) DI PERAIRAN TELUK BANTEN
}

\section{BIOLOGICAL ASPECTS OF BELANAK FISH (Mugil cephalus) IN BANTEN BAY}

\author{
Alifa Egitia Nuringtyas $\bowtie$, Alya Putri Larasati, Futra Septiyan, Ilham Mulyana, Waode Israwati, \\ Acacia Z. Araminta Mourniaty, Winda Nainggolan ${ }^{1}$, Ratna Suharti, Meuthia A. Jabbar \\ 1Prodi Teknologi Pengelolaan Sumberdaya Perairan Sekolah Tinggi Perikanan \\ JI. AUP No. 1 Pasar Minggu-Jakarta Selatan; Telepon +21-7805030 Jakarta 12520 \\ Email: alifaegitian@gmail.com
}

\begin{abstract}
ABSTRAK
Ikan Belanak (Mugil cephalus) merupakan salah satu jenis ikan perairan laut yang berhabitat di perairan muara sebagai tempat hidupnya termasuk di muara sungai di Teluk Banten. Penelitian ini bertujuan untuk mengetahui aspek biologi ikan belanak meliputi-distribusi ukuran, hubungan panjang bobot, ukuran pertama kali tertangkap (Lc). Pengamatan ini dilakukan pada bulan Maret - April 2019 di perairan Teluk Banten. Hasil penelitian menunjukkan bahwa kisaran ukuran ikan belanak antara $7-47$ $\mathrm{cm}$. Pola pertumbuhan ikan belanak di Karangantu adalah allometrik negatif $(b<3)$ dengan $L c=16,70$. dan di Domas adalah allometrik negatif $(b<3)$ dan diasumsikan ikan belanak yang tertangkap $\mathrm{Di}$ Karangantu nilai Lc>Lm yang mengindikasikan bahwa ikan belanak di lokasi tersebut sudah pernah mengalami pemijahan sebelum tertangkap, sedangkan di Desa Domas nilai Lc<Lm yang mengindikasikan bahwa ikan belanak di lokasi tersebut belum pernah mengalami pemijahan sebelum tertangkap.
\end{abstract}

Kata Kunci : Aspek biologi, Teluk Banten, Ikan Belanak

\begin{abstract}
Belanak fish (Mugil cephalus) is a type of sea water fish that uses estuary waters habitat as its place of life including in the river estuary in Banten Bay. The aim of this research is to determine the biological aspects of belanak fish biology including wich cover: size distribution, length weight relationship, length at first captured (Lc), this observation was conducted in months March - April 2019 in Banten Bay waters. The results showed that the size range of mullets between $7-47 \mathrm{~cm}$. The growth pattern of mullets in Karangantu is allometric negative $(b<3)$ with $L c=16.70$. and in Domas is negative allometric $(b<3)$ and assumed that mulled fish caught in Karangantu has a value of $L c>L m$ which indicates that the mulled fish in that location has experienced spawning before being caught, whereas in Domas Village the value of $L c<L m$ indicates that the fish mullets at these locations had never been spawned before being caught.
\end{abstract}

Keywords: Biological aspects, Banten Bay, Mugil cephalus

\section{PENDAHULUAN}

Perairan Teluk Banten terletak di Kabupaten Serang Provinsi Banten pada posisi geografis $05^{\circ} 49^{\prime} 45^{\prime \prime}-06^{\circ} 02^{\prime} 00^{\prime \prime}$ LS dan $106^{\circ} 03^{\prime} 00^{\prime \prime}-106^{\circ} 16^{\prime} 00^{\prime \prime}$ BT, dibatasi oleh Tanjung Piatu di sebelah barat dan Tanjung Pontang di sebelah timur (Hariyadi, 2016). Teluk Banten merupakan perairan semi tertutup yang menghadap Pantai Utara Jawa dengan luas sekitar $120 \mathrm{~km}^{2}$ dengan kedalaman tidak lebih dari $25 \mathrm{~m}$ (Prasadi et al., 2016). Perairan Teluk Banten dimanfaatkan oleh banyak kegiatan, di antaranya adalah perikanan tangkap, budidaya perairan, pariwisata, dan konservasi terumbu karang (Ernaningsih et al., 2013). Teluk Banten merupakan salah satu lokasi berkembangnya perikanan tradisional di wilayah Propinsi Banten, 
yang ditunjukkan dengan beragamnya alat tangkap yang digunakan untuk menangkap berbagai macam jenis ikan (Ernaningsih, 2013) termasuk ikan belanak.

Ikan Belanak (Mugil cephalus) merupakan salah satu jenis ikan perairan laut yang menggunakan habitat perairan muara sebagai tempat hidupnya termasuk di muara sungai di Teluk Banten (Sugiarti et al., 2013). Perairan muara sudah lama dikenal sebagai tempat pemijahan, tempat mencari makan, tempat asuhan dan tempat berlindung biota bahari yang ekonomis penting seperti ikan dan udang baik pada tingkat dewasa atau larva (Hariyadi, 2016). Belanak mempunyai toleransi yang lebar terhadap salinitas dan suhu, serta mampu menyesuaikan diri dengan berbagai makanan yang ada di habitatnya (Gustiana, 2013). Oleh sebab itu, ikan belanak banyak dijumpai di perairan pantai (Widianingroem et al., 2003), perairan payau hingga sungai-sungai yang tersebar di wilayah tropis dan subtropis.

Informasi aspek biologi ikan Belanak (Mugil cephalus) diharapkan dapat memberikan alternatif pengelolaan ikan Belanak (Mugil cephalus) di Teluk Banten untuk mewujudkan pemanfaatan ikan belanak yang lestari dan berkelanjutan. Penelitian ini bertujuan untuk mengetahui aspek biologi yang diamati meliputi distribusi ukuran, hubungan panjang bobot, ukuran pertama kali tertangkap $\left(\mathrm{L}_{\mathrm{C}}\right)$.

\section{METODE PRAKTIK}

Penelitian ini telah dilaksanakan pada 4 Maret sampai 18 April 2019, di perairan teluk Banten dengan lokasi pengambilan sampel di 3 lokasi yaitu Pelabuhan Perikanan Karangantu, TPI Domas. Nelayan menangkap ikan Belanak dengan menggunakan gill net. Stasiun pengamatan disajikan pada Gambar 1.

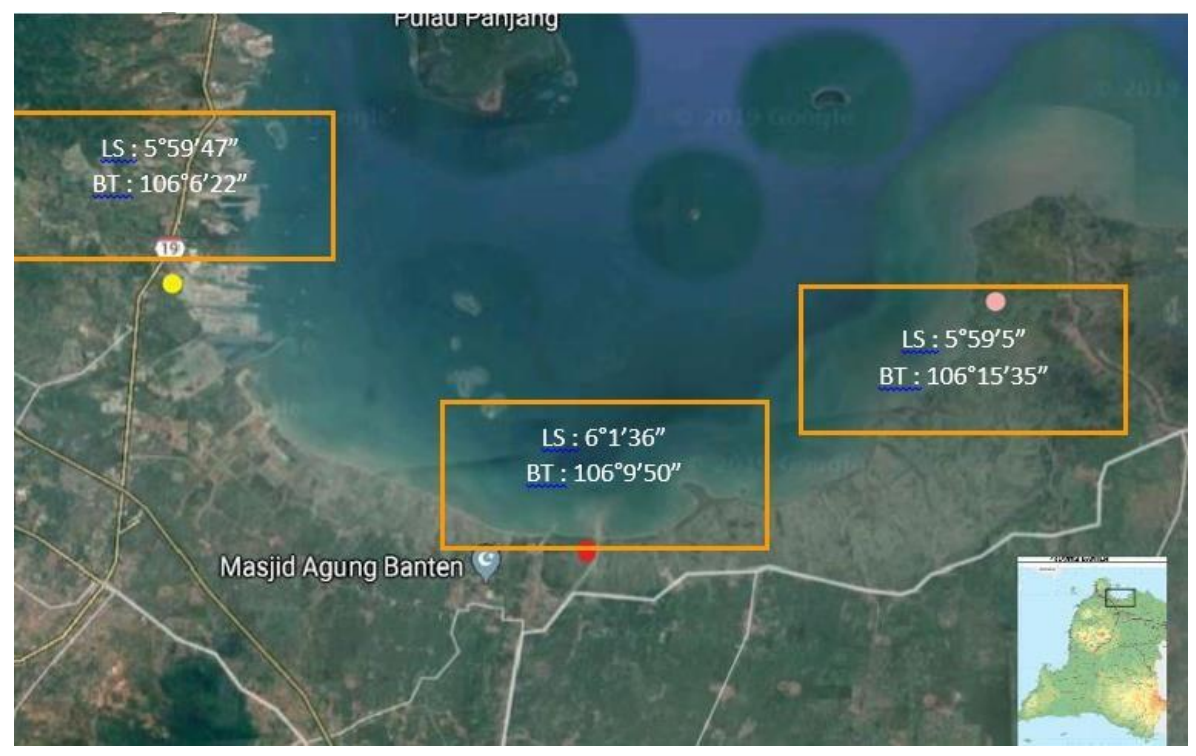

Gambar 1. Stasiun Pengamatan

Pengumpulan data berdasarkan responden dilakukan secara accidential sampling yaitu pengambilan data secara sengaja kepada para penjual ikan belanak yang akan dijadikan sebagai responden. Pengumpulan data untuk pengambilan sampel ikan belanak dengan alat tangkap gill net dilakukan dengan metode sensus dengan mengambil sampel untuk pengukuran panjang dan berat ikan sebanyak $10 \%$ dari total hasil tangkapan. Setiap sampel ikan diukur panjang dalam satuan sentimeter $(\mathrm{cm})$ dan berat tubuh dalam gram $(\mathrm{g})$. Panjang ikan diukur dari bagian paling depan ujung mulut hingga pangkal ekor. Pengukuran panjang tidak sampai pada ujung ekor karena ekor sangat rawan hilang atau putus. 


\section{Buletin JSJ, 1 (2), 2019, 81-77}

Available online di: http://ejournal-balitbang.kkp.go.id/index.php/JSJ/index

Analisis mengenai hubungan panjang berat ikan belanak dianalisis dengan persamaan Pauly (1984) :

$$
\mathrm{W}=\mathrm{aLb}
$$

Dimana $W$ adalah berat ikan (gram) dan $L$ merupakan panjang ikan $(\mathrm{cm})$, dimana a adalah intersep dan $b$ adalah slope atau kemiringan. Nilai koefisien ' $b$ ' hasil regresi tersebut dapat memberikan informasi mengenai pola pertumbuhan suatu jenis ikan. Ketika nilai $b=3$ maka dikatakan sebagai suatu jenis ikan memilki pola pertumbuhan isometrik, sedangkan $b>3$ menunjukkan allometrik positif dan allometrik negatif untuk $b<3$. Kemudian diuji melalui t-test pada taraf nyata $95 \%$ atau á $=0,05$ untuk memastikan jika nilai yang diperoleh berbeda secara nyata dari 3 (Oktaviyani et al., 2016).Panjang ikan pertama kali tertangkap (LC) diduga melalui metode Sparre \& Venema (1998):

$$
S L=\frac{1}{1+\exp (S 1-S 2+L)}
$$

Nilai Lc50\% diperoleh dengan memplotkan persentase frekuensi kumulatif ikan yang tertangkap dengan ukuran panjang cagaknya, dimana titik potong antara kurva $50 \%$ frekuensi kumulatif adalah panjang saat $50 \%$ ikan tertangkap. Sehingga panjang pada saat $50 \%$ tertangkap (Lc) sama dengan -a/b.

\section{HASIL DAN PEMBAHASAN}

\section{Distribusi Frkuensi Panjang}

Jumlah Ikan belanak yang diamati selama praktik yaitu sebanyak 1350 ekor yang diperoleh dari wilayah Karangantu sebanyak 830 ekor dan 520 ekor di Desa Domas. Ikan belanak pada setiap lokasi memiliki ukuran panjang serta bobot tubuh ikan yang berbeda-beda. Kisaran panjang ikan belanak di wilayah Karangantu yaitu berkisar $7-47 \mathrm{~cm}$ dengan bobot tubuh ikan berkisar 5 - 176 gram. Sedangkan ikan belanak di Desa Domas memiliki panjang dengan kisaran $7.8-47 \mathrm{~cm}$ dan memiliki bobot tubuh ikan yang berkisar 6 - $152.5 \mathrm{gram}$. Distribusi frekuensi panjang dapat dilihat pada Gambar 2.

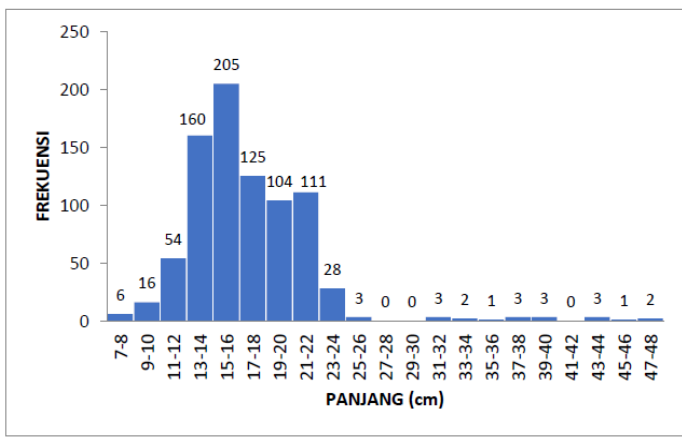

(a)

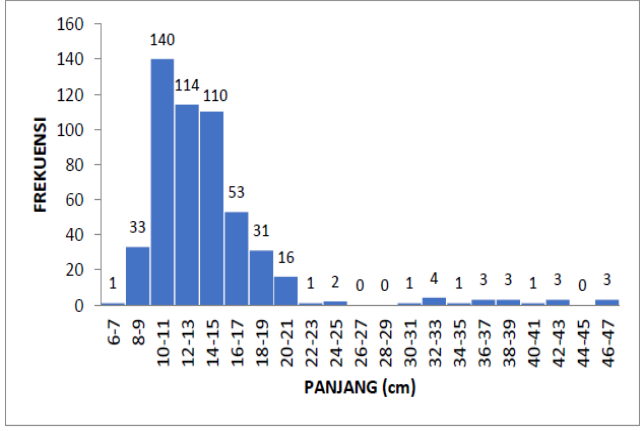

(b)

Gambar 2. Distribusi frekuensi (a) ikan belanak di Karangantu (b) ikan belanak di Domas

Pengelompokkan ikan berdasarkan ukuran panjang juga dapat menentukan kelompok umur ikan, ikan belanak di wilayah Karangantu dan Domas terdiri dari 1 kelompok usia (1 kohort) dengan ukuran dominan pada setiap lokasi yaitu pada selang kelas $15-16 \mathrm{~cm}$ di wilayah Karangantu dan pada selang kelas $10-11 \mathrm{~cm}$ untuk ikan di wilayah Domas.

Berdasarkan perbandingan trend grafik pada kedua gambar terlihat bahwa kondisi ikan 
belanak di wilayah Karangantu memiliki ukuran yang lebih panjang dibandingkan di Desa Domas. Al Ghiffary et al., (2018) menyatakan bahwa perbedaan ukuran panjang yang tertangkap dapat mengindikasikan adanya perbedaan umur serta musim pemijahan ikan tersebut dan akan berkaitan dengan kondisi habitatnya. Adanya perbedaan ukuran panjang tersebut dapat disebabkan oleh beberapa faktor seperti perbedaan alat tangkap yang digunakan dalam penangkapan ikan di kedua lokasi. Alat tangkap yang digunakan dalam penelitian menjadi faktor penting karena selektivitas alat tangkap yang tinggi menyebabkan ikan yang tertangkap mempunyai ukuran yang hampir seragam sedangkan selektivitas alat tangkap yang rendah mengakibatkan ukuran hasil tangkapan lebih beragam (Sulistiono dkk, 2017). Selain itu, daerah penangkapan (fishing ground) yang berbeda juga dapat mempengaruhi perbedaan tersebut.

\section{Hubungan Panjang Bobot Ikan Belanak (Mugil cephalus)}

Hasil analisis hubungan panjang bobot ikan belanak sebanyak 1350 ekor yang diperoleh dari wilayah Karangantu dan Desa Domas, diperoleh nilai b sebesar 0,7918 untuk ikan belanak di wilayah Karangantu dan nilai $b=1,4150$ untuk ikan belanak di Desa Domas, sehingga persamaan hubungan panjang bobot ikan belanak di wilayah Karangantu menjadi $\mathrm{W}=5.4506 \mathrm{~L} 0.7918$ dan $\mathrm{W}=0.6465 \mathrm{~L} 1,4150$ untuk ikan belanak di Desa Domas. Koefisien determinasi (R2) yang diperoleh ikan belanak pada kedua lokasi tersebut

berturut-turut sebesar 0.2313 dan 0.1647 . Jika nilai $R 2$ mendekati 1 maka panjang total ikan akan semakin bertambah seiring pertambahan bobot tubuh ikan. Namun, nilai R2 yang diperoleh sangat kecil sehingga menunjukan bahwa hanya $16,47 \%$ dan $23.13 \%$ dari keseluruhan ikan belanak yang dapat menjelaskan bahwa pertambahan panjang diikuti dengan pertambahan berat di wilayah Karangantu dan Desa Domas (Fuadi dkk, 2016). Berikut merupakan hasil parameter analisis hubungan panjang bobot ikan belanak (Mugil cephalus) yang disajikan pada Tabel 1.

Tabel 1. Nilai parameter dalam hubungan panjang bobot ikan belanak (Mugil cephalus) di Wilayah Karangantu dan Desa Domas

\begin{tabular}{rlrr}
\hline No & Parameter & \multicolumn{1}{c}{ Karangantu } & \multicolumn{1}{c}{ Domas } \\
\hline 1 & Jumlah sampel (ekor) & 830 & 520 \\
2 & Koefisien regresi (b) & 0,7918 & 1,4150 \\
3 & Koefisien determinasi $\left(\mathrm{R}^{2}\right)$ & 0.2313 & 0.1647 \\
4 & Persamaan regresi & $\mathrm{W}=5.4506 \mathrm{~L}^{0.7918}$ & $\mathrm{~W}=0.6465 \mathrm{~L}^{1,4150}$ \\
5 & Uji t & $\mathrm{T} \mathrm{hitung}>\mathrm{T}$ tabel & $\mathrm{T} \mathrm{hitung}>\mathrm{T}$ tabel \\
& & $9,2246>1,9630$ & $42,3495>1,9630$ \\
6 & Pola Pertumbuhan & Allometrik negatif & Allometrik negatif \\
\hline
\end{tabular}

Berdasarkan uji t pada selang kepercayaan 95\% diperoleh pola pertumbuhan ikan belanak pada kedua lokasi tersebut sama yaitu allometrik negatif, yang berarti pertambahan panjang lebih cepat dibandingkan pertambahan bobot yang menunjukan keadaan ikan ramping. Hubungan panjang berat dapat dilihat pada Gambar 3. Wigati \& Syafei (2017) yang ditandai dengan hasil analisis yang menunjukan bahwa nilai $b<3$ yang artinya ikan belanak di kedua wilayah tersebut memiliki pola pertumbuhan yang tidak seimbang antara pertumbuhan panjang total tubuh dan berat tubuhnya $(b \neq 3)$, yang menunjukkan pertambahan panjang ikan belanak lebih cepat dibandingkan pertambahan beratnya (Pratiwi, 2011.). Hubungan panjang berat dapat memberikan informasi tentang kondisi biota, dimana berat biota akan meningkat sehubungan dengan meningkatnya volume (Fadhil et al., 2016). 
Buletin JSJ, 1 (2), 2019, 81-77

Available online di: http://ejournal-balitbang.kkp.go.id/index.php/JSJ/index

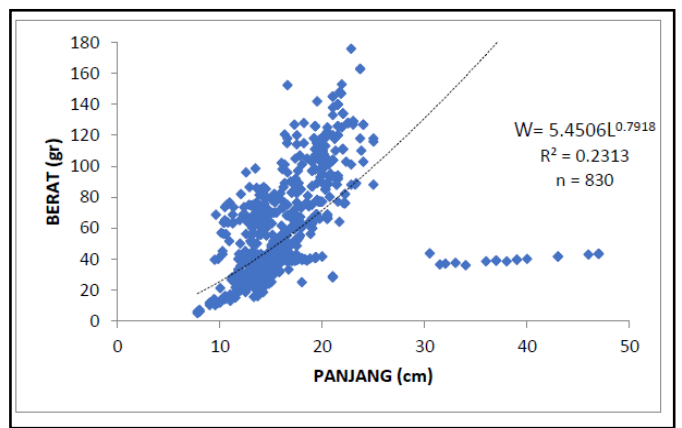

(a)

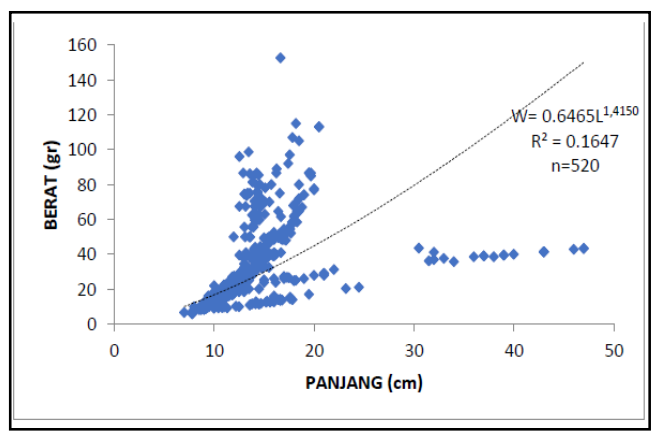

(b)

Gambar 4. Hubungan Panjang Bobot Ikan Belanak (Mugil cephalus) di wilayah Domas (a) dan Desa Karangantu (b)

Menurut Ibrahim et al., (2018), pengaruh ukuran panjang dan bobot tubuh ikan sangat besar terhadap nilai b yang diperoleh sehingga secara tidak langsung faktor-faktor yang berpengaruh terhadap ukuran tubuh ikan akan mempengaruhi pola variasi dari nilai b. Variasi nilai b disebabkan oleh berbagai faktor, seperti jumlah contoh ikan yang diukur (semakin banyak contoh akan semakin akurat), kondisi perairan dan musim (Damora \& Wagiyo, 2012). Ketersediaan makanan, tingkat kematangan gonad, dan variasi ukuran tubuh ikan contoh juga dapat menjadi penyebab perbedaan nilai b tersebut. Selain itu, juga dapat dipengaruhi oleh tingkah laku ikan yang melakukan pergerakan aktif dan ruaya.

\section{Panjang Pertama Kali Ikan Belanak (Mugil cephalus) Tertangkap (Lc)}

Panjang ikan pertama kali tertangkap (Lc) merupakan hal yang penting untuk dipelajari. Jika dihubungkan dengan panjang pertama kali matang gonad $(\mathrm{Lm})$ maka dapat diketahui status populasinya (Damora \& Ernawati, 2017). Ukuran pertama kali ikan belanak (Mugil cephalus) tertangkap (Lc) dapat dilihat pada Gambar 4.

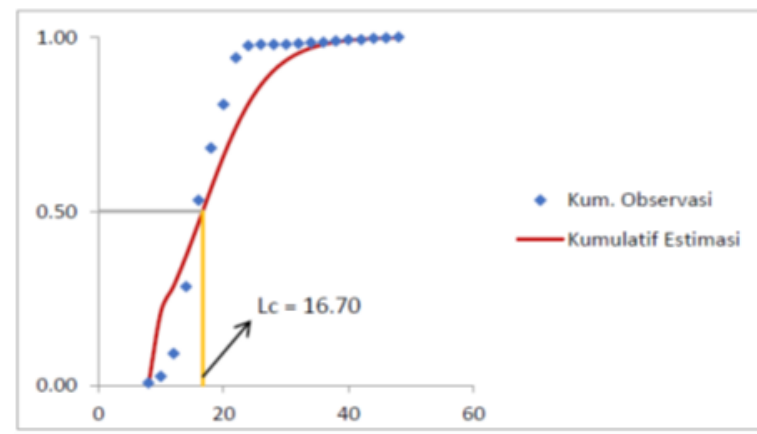

(a)

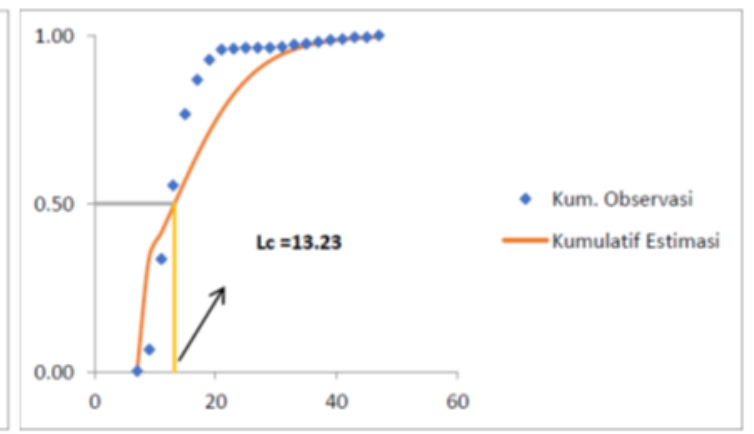

(b)

Gambar 4. Ukuran Pertama Kali Tertangkap (Lc) Ikan Belanak (Mugil cephalus) di Wilayah Karangantu (a) dan Desa Domas (b)

Berdasarkan hasil analisis menunjukan bahwa nilai Lc untuk ikan belanak di wilayah Karangantu adalah $16.70 \mathrm{~cm}$ dan di desa Domas adalah $13.23 \mathrm{~cm}$. Hasil penelitian yang dilakukan (Okfan et al., 2015) nilai Lm ikan belanak sebesar 14,2 cm. Berdasarkan hasil tersebut ikan belanak yang tertangkap di daerah Karangantu sudah pernah memijah setidaknya satu kali sebelum tertangkap, sedangkan di desa Domas belum matang gonad atau belum melakukan proses rekruitmen (individu baru) sehingga apabila hal ini terjadi terusmenerus maka secara biologi, pengelolaan ikan akan menjadi tidak berkelanjutan (Ardelia dkk, 2016). 
Buletin JSJ, 1 (2), 2019, 63-69

Available online di: http://ejournal-balitbang.kkp.go.id/index.php/JSJ/index

\section{KESIMPULAN DAN SARAN}

Hasil dari peneilitian Ikan Belanak (Mugil cephalus) di Karangantu dan Domas memiliki pola pertumbuhan allometrik negatif. Ikan belanak memiliki ukuran pertama kali tertangkap (Lc) yang berbeda. Di Karangantu nilai Lc>Lm yang mengindikasikan bahwa ikan belanak di lokasi tersebut sudah pernah mengalami pemijahan sebelum tertangkap, sedangkan di Desa Domas nilai Lc<Lm yang mengindikasikan bahwa ikan belanak di lokasi tersebut belum pernah mengalami pemijahan sebelum tertangkap.

\section{DAFTAR PUSTAKA}

Al Ghiffary, G. A. A. D., Rahardjo, M. F., Zahid, A., Simanjuntak, C. P. H., Asriansyah, A., \& Aditriawan, R. M. 2018. Komposisi Dan Luas Relung Makanan Ikan Belanak Chelon Subviridis (Valenciennes, 1836) Dan Moolgarda Engeli (Bleeker, 1858) Di Teluk Pabean, Kabupaten Indramayu, Provinsi Jawa Barat. Jurnal Iktiologi Indonesia, 18(1), 41. Https://Doi.Org/10.32491/Jii.V18i1.373

Ardelia, V., Vitner, Y., \& Boer, M. 2016. Biologi Reproduksi Ikan Tongkol Euthynnus Affinis Di Perairan Selat Sunda. Jurnal IImu Dan Teknologi Kelautan Tropis, 8 (2), 689-700,.

Damora, A., \& Wagiyo, K. 2012. Parameter Populasi lkan Kadah (Valamugil Speigleri) Sebagai Indikator Pemanfaatan Sumber Daya Perairan Estuariadi Pemalang. BAWAL Widya Riset Perikanan Tangkap, Vol. 4 (2), 91-96.

Ernaningsih, D. 2013. Analisis Bioekonomi Ikan Pelagis Kecil Di Teluk Banten (Jurnal).Docx.

Ernaningsih, D., Simbolon, D., Wiyono, E. S., \& Purbayanto, A. 2013. Komoditi Unggulan Perikanan Tangkap Di Teluk Banten ( Leading Commodity Of Capture Fisheries In Banten Bay. Buletin PSP, 20(2), 181-192.

Fadhil, R., Muchlisin, Z. A., \& Sari, W. 2016. Hubungan Panjang-Berat Dan Morfometrik Ikan Julungjulung (Zenarchopterus Dispar) Dari Perairan Pantai Utara Aceh. Jurnal Ilmiah Mahasiswa Kelautan Perikanan Unsyiah, 1(1).

Fuadi, Z., Dewiyanti, I., \& Purnawan, S. 2016. Hubungan Panjang Berat Ikan Yang Tertangkap Di Krueng Simpoe, Kabupaten Bireun, Aceh. 1, 8.

Gustiana, M. 2013. Hubungan Panjang-Berat Dan Faktor Kondisi Belanak (Liza Subviridis) Di Estuari Opak Kabupaten Bantul. Universitas Gadjah Mada.

Hariyadi, S. 2016. Keterkaitan Antara Kualitas Air Dengan Hasil Tangkapan Ikan Di Muara Sungai Teluk Banten, Provinsi Banten.

Ibrahim, P. S., Setyobudiandi, I., \& Sulistiono. 2018. Hubungan Panjang Bobot Dan Faktor Kondisi Ikan Selar Kuning Selaroides Leptolepis Di Perairan Selat Sunda. Jurnal IImu Dan Teknologi Kelautan Tropis, 9(2), 577. Https://Doi.Org/10.29244/Jitkt.V9i2.19292

Oktaviyani, S., Boer, M., \& Yonvitner. 2016. Biological Aspects of Japanese Threadfin Bream (Nemipterus japonicus) in The Gulf Of Banten, 8(April), 21-28

Okfan, A., Muskananfola, M. R., \& Djuwito. 2015. Studi Ekologi Dan Aspek Biologi Ikan Belanak (Mugil Sp.) Di Perairan Muara Sungai Banger, Kota Pekalongan. Fakultas Perikanan Dan IImu Kelautan, Universitas Diponegoro, 4(3), 156-163.

Pauly, D. 1984. Fish Population Dynamics In Tropical Waters: A Manual For Use With Programmable Calculators. Fisheries Research, 4(2), 171-173. Https://Doi.Org/10.1016/0165-7836(86)90044-5 
Available online di: http://ejournal-balitbang.kkp.go.id/index.php/JSJ/index

Prasadi, O., Setyobudiandi, I., Butet, N. A., \& Nuryati, S. 2016. Karakteristik Morfologi Famili Arcidae Di Perairan Yang Berbeda (Karangantu Dan Labuan, Banten). Jurnal Teknologi Lingkungan, 17(1), 29. Https://Doi.Org/10.29122/Jtl.V17i1.1462

Pratiwi, E. I. 2011. Program Studi Pendidikan Biologi Jurusan PMIPA Fakultas Keguruan Dan IImu Pendidikan Universitas Tanjungpura Pontianak. 17.

S.A, D. S., Widianingroem, R., \& Soeparno. 2003. Hubungan Panjang-Berat Dan Faktor Kondisi Relatif Belanak (Liza Subviridis) Di Laguna Lereng Kabupaten Purworejo. Jurnal Perikanan Universitas Gadjah Mada, 5(2), 24-31.

Sparre, P., \& Venema, S. 1998. Introduction To Tropical Fish Stock Assessment. Part 1. Manual. FAO Fish. Tech. Paper., 306(1), 1-407.

Sugiarti, Hariyadi, S., \& Nasution, S. H. 2013. Hubungan Panjang Berat Ikan Belanak (Mugil Cephalus) Di Tiga Muara Sungai Di Teluk Banten.

Sulistiono, Muhamad Arwani, \& K.A. Aziz. 2017. Pertumbuhan Ikan Belanak (Mugil Dussumieri) Di Perairan Ujung Pangkah, Jawa Timur [Growth Of Mullet, Mugil Dussumieri In Ujung Pangkah, East Java]. Vol L. No 2.

Wigati, K. \& Syafei, L. 2017. Biologi Reproduksi Ikan Belanak (Moolgarda Engeli, Bleeker 1858) Di Pantai Mayangan, Jawa Barat [Reproduction And Spawning Patterns Of The Mullet (Moolgarda Engeli, Bleeker 1858) In Mayangan Coastal Waters, West Java]. Jurnal Iktiologi Indonesia, 13 (2), 125-132. 